\title{
Ecological Growth Strategies in the Seaweeds Gracilaria foliifera (Rhodophyceae) and Ulva sp. (Chlorophyceae): Photosynthesis and Antenna Composition
}

\author{
G. Rosenberg ${ }^{1 *}$ and J. Ramus ${ }^{2}$ \\ 1 Yale University, Department of Biology, Osborn Memorial Laboratories, New Haven, Connecticut 06520, USA \\ 2 Duke University Marine Laboratory, Beaufort, North Carolina 28516, USA
}

\begin{abstract}
Observations have been made on photosynthesis (oxygen evolution) and seasonal fluctuations in antenna pigments in 2 seaweeds which co-occur in the vicinity of Beaufort, North Carolina, USA. Gracilaria foliffera (Rhodophyceae) and Ulva sp. (Chlorophyceae) were grown in outdoor continuous-flow cultures at ambient incident light $\left(\mathrm{I}_{0}\right)$ and $13 \mathrm{I}_{0}$. Pigment contents and accessory pigment: chlorophyll a ratios were higher at $13 \mathrm{I}_{\mathrm{o}}$ than at $\mathrm{I}_{\mathrm{o}}$. Total pigment levels were correlated with soluble $\mathrm{N}$ in seaweed tissue. During the spring/summer growing season, pigment levels were low and peaks in pigment content followed nutrient pulses in the ambient seawater. Pigment contents in both species were higher in winter. In G. foliffera, the R-phycoerythrin: chl a ratio was highest in fall-winter and lowest in summer. The higher growth rates achieved by Ulva sp. reflected the higher rates of photosynthesis measured in this species. Photosynthesis-light curves showed that Ulva sp. had a higher photosynthetic capacity $\left(\mathrm{P}_{\max }=430 \mu \mathrm{mol} \mathrm{O}_{2}\right.$ evolved $\mathrm{g}$ dry $\mathrm{wt}^{-1} \mathrm{~h}^{-1}$ ) and initial slope (in shadeacclimated plants) than $G$. folifera $\left(\mathrm{P}_{\max }=160 \mu \mathrm{mol} \mathrm{O}_{2}\right.$ evolved $\mathrm{g}$ dry $\left.\mathrm{wt}^{-1} \mathrm{~h}^{-1}\right)$. Increased pigment contents in shade plants of both species resulted in enhanced photosynthetic performance at subsaturating light intensities. It appears that the effect of transient pigment increases in the summer was to increase $P_{\max }$ temporarily while, in winter, the effect was to limit the decrease in integrated net photosynthesis in the face of decreased light and temperature.
\end{abstract}

\section{INTRODUCTION}

Accomodation of the seaweed photosynthetic apparatus to variations in light, nutrients, or temperature in the environment may involve changes in both the concentration and ratios of antenna pigments within the thallus. Ramus et al. (1976a, b; 1977) have studied accommodation to photon flux density in several species representing the 3 taxonomic classes of seaweeds. All of the seaweeds tested increased antenna pigment content with decreasing incident light and, in most species, this was accompanied by an increase in the accessory pigment: chlorophyll a ratio. These changes were reversible and did not require cell division. There is comparatively less information avail-

\footnotetext{
- Present address: Department of Biology, Dalhousie University, Halifax, Nova Scotia, B3H 4J1 Canada
}

able regarding seasonal variations in pigment concentration and ratios.

According to Platt et al. (1977), most of the variance in primary production is accounted for by fluctuations in light. Thus, the scope for growth in a particular habitat should reflect the form of the photosynthesislight (P vs. I) curve. The characteristics of this curve are, in turn, affected by physiological manipulation of the photosynthetic antenna. Inasmuch as the photosynthetic antenna accounts for much of the protein in plant tissue (Ramus, in press), photosynthesis may also be regulated by $\mathrm{N}$-nutrient availability (LaPointe and Ryther, 1979).

The red seaweed Gracilaria foliffera and the green seaweed Ulva sp. co-occur in the vicinity of Beaufort, North Carolina. When the 2 species were grown together in an outdoor continuous-flow system, Ulva sp. had a higher growth rate than $G$. foliifera (Rosen- 
berg, 1981). The difference between the growth rates of the 2 species was greater at ambient incident light $\left(I_{0}\right)$ than at $.13 I_{0}$. The aims of this study were (1) to determine how the growth rates of these species were related to photosynthetic performance (oxygen evolution) and (2) to determine the seasonal fluctuations in antenna pigment content in response to photon flux density and nutrient availability.

\section{MATERIALS AND METHODS}

Gracilaria foliifera (Forsskål) Børgesen and Ulva sp. were collected at monthly intervals from November, 1978, to February, 1980 (total of 14 collections). G. foliifera was always obtained from Fort Macon jetty $\left(34^{\circ} 42^{\prime} \mathrm{N} .76^{\circ} 41^{\prime} \mathrm{W}\right.$.) near Beaufort, North Carolina. In November and December, 1978, only, Ulva sp. was also obtained from the jetty. Beginning in January, 1979, the monthly collections of Ulva sp. were made at a nearby site, Bird Shoal, in order to avoid causing excessive damage to the population on the jetty.

The 2 populations were originally thought to consist of Ulva lactuca Linnaeus. Recently, R. B. Searles (pers. comm.) has suggested that the 2 populations may represent distinct Ulva species. Reexamination of preserved specimens using a revised taxonomic key (R. B. Searles, unpubl.) resulted in tentative identification of the Ulva sp. from Bird Shoal as Ulva curvata (Kützing) DeToni; that from the jetty is tentatively identified as Ulva rigida C. Agardh. In view of the uncertain taxonomical distinctions within the genus (Provasoli and Pintner, 1980; C. Yarish, pers. comm.), reference will be made to 'Ulva sp.'.

Following collection, the seaweeds were returned to the laboratory where they were blotted and cut to yield individual plants weighing $0.50 \pm 0.05 \mathrm{~g}$ fresh weight (ca. $5 \mathrm{~cm}$ in length) for Gracilaria foliffera and $0.25 \pm$ $0.025 \mathrm{~g}$ fresh weight (ca. $25 \mathrm{~cm}^{2}$ surface area) for Ulva $\mathrm{sp}$. Four individuals were then placed in each of a number of small Plexiglas tubes $110 \mathrm{~cm}$ long, $5 \mathrm{~cm}$ diameter) which were riddled with holes and closed at the ends with wide-mesh $(7 \mathrm{~mm})$ plastic screening.

The Plexiglas tubes were then suspended in several outdoor continuous-flow seawater tanks (140 l capacity) at the Duke University Marine Laboratory where they were exposed to ambient environmental conditions. In order to simulate the decreased photon flux density in the low intertidal zone, seaweeds were also grown at $13 \%$ of ambient incident light $\left(I_{0}\right.$, measured just above the surface of the water in the tanks) obtained using fiberglass neutral-density filters. Two weeks were more than sufficient for complete physiological acclimation (J. Ramus, unpubl.). Seaweeds grown at $\mathrm{I}_{\mathrm{o}}$ are herein termed 'sun plants'; seaweeds grown at $.13 \mathrm{I}_{0}$ are 'shade plants'.

Average daily incident light $\left(\mathrm{I}_{o}\right)$ ranged from $31 \mathrm{E}$ $\mathrm{m}^{-2} \mathrm{~d}^{-1}$ in December to $80 \mathrm{E} \mathrm{m}^{-2} \mathrm{~d}^{-1}$ in midsummer. Water temperature ranged from $5^{\circ} \mathrm{C}$ in January-February to $30^{\circ} \mathrm{C}$ in July-August. N-nutrient levels (mostly as ammonium) in the outdoor tanks were variable. The inorganic nitrogen concentration was usu-

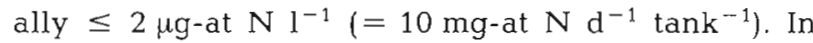
1979, nutrient pulses were observed in July (up to $6 \mu \mathrm{g}$ at $\mathrm{N} \mathrm{l}^{-1}=28 \mathrm{mg}$-at $\mathrm{N} \mathrm{d}^{-1} \operatorname{tank}^{-1}$ ) and again in September (up to $10 \mu \mathrm{g}$-at $\mathrm{N} \mathrm{l}^{-1}=46 \mathrm{mg}$-at $\mathrm{N} \mathrm{d}^{-1}$ $\left.\operatorname{tank}^{-1}\right)$. High flow rates at the beginning of the study resulted in a peak of $118 \mathrm{mg}$-at $\mathrm{N} \mathrm{d}^{-1} \operatorname{tank}^{-1}$ in December, 1978.

After 2 wk in the outdoor tanks, the acclimated seaweeds were harvested and reweighed. After reweighing, all of the seaweeds, except for the individuals used for dry weight determination ( $\mathrm{n}=11$ ), were placed in plastic Whirlpak bags and stored frozen at $-15^{\circ} \mathrm{C}$ for subsequent tissue analysis. Dry weights were determined after desiccation for $24 \mathrm{~h}$ at $90^{\circ} \mathrm{C}$.

Photosynthetic pigment analyses were carried out using five separate individuals of each species. Plantto-plant variance within each treatment is reported as the average coefficient of variation $[\mathrm{CV}=(\sigma / \overline{\mathrm{x}}) \times 100]$ for each analysis. Chlorophyll a $(\mathrm{chl} a, \mathrm{CV}=20 \%)$ and accessory chl $b$ (in Ulva sp. only, CV $=26 \%$ ) were extracted from thawed samples by breaking the tissue in $90 \%$ acetone (in the presence of $\mathrm{MgCO}_{3}$ ) in a chilled, motor-driven Ten Broeck tissue homogenizer. Following centrifugation, the chl $a$ and $b$ concentrations were calculated from the spectrophotometric equations (for Ulva sp.) or extinction coefficients (for Gracilaria foliifera) of Jeffrey and Humphrey (1975). Total carotenoid concentrations $(\mathrm{CV}=23 \%)$ were estimated using the equation of Strickland and Parsons (1972). All absorbances were measured on a Beckman Model 25 double-beam grating spectrophotometer.

The accessory phycobiliproteins were extracted from Gracilaria foliifera by breaking the tissue in $0.05 \mathrm{M}$ phosphate buffer, pH 6.7 (Siegelman and Kycia, 1978). The homogenate was allowed to extract at $4{ }^{\circ} \mathrm{C}$ for $30 \mathrm{~min}$, with occasional stirring. Repeated extractions yielded little additional pigment. Following centrifugation, the absorbance of the supernatant was read at $565 \mathrm{~nm}, 615 \mathrm{~nm}$, and $650 \mathrm{~nm}$. The concentrations of Rphycoerythrin (R-PE, $\lambda_{\max }=565 \mathrm{~nm} ; \mathrm{CV}=32 \%$ ) and the minor phycobiliproteins, $\mathrm{R}$-phycocyanin $\left(\lambda_{\max }=\right.$ $615 \mathrm{~nm})$ and allophycocyanin $\left(\lambda_{\max }=650 \mathrm{~nm}\right)$, were calculated according to the trichromatic spectrophotometric equations given in Rosenberg (1981).

Total soluble nitrogen in seaweed tissue $(\mathrm{CV}=$ $15 \%$ ) was determined by breaking the thawed samples in distilled deionized water. Following centrifu- 
gation, the supernatant was analyzed for total persulfate nitrogen (TPN $=$ total Kjeldahl nitrogen + nitrite + nitrate) according to the method of D'Elia et al. (1977) with a nitrate solution as a standard.

Photosynthesis-light ( $P$ vs. I) curves were obtained for both freshly collected material and seaweeds acclimated at $\mathrm{I}_{0}$ or $.13 \mathrm{I}_{0}$. Laboratory incubations were carried out by enclosing the seaweeds in a standard biological oxygen demand (BOD) bottle filled with filtered seawater. This bottle was then placed in a Sherer Model 2-113 incubator at ambient water temperature $\left(14^{\circ} \mathrm{C}\right)$. Light was provided by a bank of 12 'cool-white' fluorescent tubes (Sylvania F48T12-CWVHO) and could be attenuated using neutral-density filters. Photon flux density was measured using a Licor 193S $4 \pi$ quantum sensor connected to a Licor Model 550 printing integrator. The quantum sensor measured only photosynthetically active radiation (PAR, 400-700 nm, as $\mu \mathrm{E} \mathrm{m}^{-2} \mathrm{~s}^{-1}$ ). Mixing was provided by a magnetic stir bar. As the photon flux density was increased stepwise, oxygen levels were continuously monitored using a Clark-type polarographic electrode (Yellow Springs Instruments Model 5750) with a YSI Model 57 oxygen meter. The oxygen meter provided input to a Fisher Recordall Series 5000 strip chart recorder. Photosynthetic rate measurements (expressed as $\mu \mathrm{mol} \mathrm{O}_{2}$ evolved $\mathrm{g}$ dry $\mathrm{wt}^{-1} \mathrm{~min}^{-1}$ ) were based on 10-min exposures at each light intensity.

Incubations were also carried out in situ by enclosing individual seaweeds in BOD bottles which were suspended from a vertically-buoyed polypropylene line at 1 -m intervals from the surface to $4 \mathrm{~m}$. Control bottles contained filtered seawater only. Mixing was promoted by placing a glass marble in each bottle. All in situ incubations were carried out around midday and lasted about $2 \frac{1 / 2}{h}$. Incident light and its attenuation in the water column were measured using either the Licor $4 \pi$ quantum sensor or a Kettering LDC Model 68 radiometer calibrated to the Licor unit. Rates of photosynthesis (expressed as $\mu \mathrm{mol} \mathrm{O}_{2}$ evolved $\mathrm{g}$ dry $\mathrm{wt}^{-1}$ $\mathrm{h}^{-1}$ ) were determined by measuring the change in dissolved oxygen. During oxygen measurements, mixing was provided by a magnetic stir bar. Dark respiration was determined by incubating the seaweeds in BOD bottles wrapped with black electrician's tape

Seaweeds were also incubated outdoors in a clear Plexiglas tank provided with circulating seawater at the ambient temperature. The seawater surrounding the BOD bottles had the effect of reducing the incident light $\left(I_{0}\right.$, measured just above the surface) to $70 \%$ of its initial value. For some measurements, the light was further attenuated to .03I。 with fiberglass neutraldensity filters wrapped around the BOD bottles. The contents of the bottles were mixed by bars turned by water-driven magnetic stirrers. Net photosynthesis and dark respiration were determined as described for the in situ incubations. Following incubation, in vivo thallus absorptance was determined with an Optronic Laboratories Model 740 autoranging scanning spectroradiometer system. The use of this device is described in Ramus (1978). Absorptance $(\alpha)$, that fraction of the incident light absorbed, was calculated as 1 - (I/ $\mathrm{I}_{0}$ ) where $\mathrm{I}_{0}=$ incident PAR and $\mathrm{I}=$ transmitted PAR

\section{RESULTS}

\section{Photosynthetic Performance}

The characteristics of the in situ P vs. I curves for freshly collected Gracilaria foliifera and UIva sp. are shown in Table 1. Ulva sp. showed higher values of $\mathrm{P}_{\text {Imax }}\left(406\right.$ vs. $150 \mu \mathrm{mol} \mathrm{O}_{2}$ evolved $\mathrm{g}$ dry $\mathrm{wt}^{-1} \mathrm{~h}^{-1}$; paired t-test, $\mathrm{p}<.01$ ) and $\mathrm{I}_{\mathrm{k}}$ (465 vs. $200 \mathrm{E} \mathrm{m}^{-2} \mathrm{~s}^{-1}$; paired t-test, $\mathrm{p}<.05$ ) than $G$. foliifera. The initial slopes of the in situ curves were similar for the two species (Table 1).

These results may be compared with similar curves for Codium decorticatum (Woodward) Howe and Dictyota dichotoma (Hudson) Lamouroux, 2 other seaweeds from the Beaufort area (Table 1). The $\mathrm{P}_{\max }$ values were higher in Ulva sp. and $D$. dichotoma, species with high surface area: volume (SA:V) ratios, than in Gracilaria foliifera and $C$. decorticatum which had lower SA:V ratios $(2$-sample t-tests, $p<.01)$. A similar pattern was found for dark respiration expressed on a dry weight basis (Table 1 ; 2 -sample t-tests, $p<.05$ ). Photoinhibition was less pronounced in the optically translucent species (Ulva sp. and $D$. dichotoma) than in seaweeds which were optically more opaque ( $G$. foliifera and C. decorticatum) (Table 1).

A comparison was made of P-I curves generated in the laboratory and in situ. The results showed that, in spite of differences in the incubation time (10 min vs. $2 \frac{1}{2} \mathrm{~h}$ ) and light regime (constant vs. fluctuating), there was good agreement between the 2 methods for freshiy collected Gracilaria foliifera and Ulva sp. Laboratory P-I curves for $G$. foliifera and Ulva sp. acclimated for 2 wk at $I_{o}$ or $.13 \mathrm{I}_{\mathrm{o}}$ are shown in Fig. 1. Ulva sp. showed higher values of $P_{\max }$ and initial slope (in shade plants) than $G$. foliifera. In both species, shade plants (with higher pigment contents) showed enhanced photosynthetic performance at all light intensities tested when compared to sun plants. However, acclimation to low light intensities also resulted in a decrease in the threshold intensity for photoinhibition (Fig. 1). At light

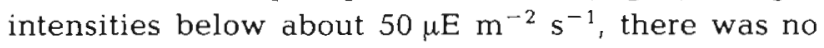
significant difference in photosynthetic performances of the two species for plants acclimated to $I_{0}$.

Comparison of the in situ P-I curves for freshly col- 
Table 1. Summary of the characteristics of in situ P vs. I curves for 4 species of seaweeds collected in late summer to early fall (1979) near Beaufort, North Carolina (USA). $P_{\max }$ : photosynthetic capacity; $I_{k}$ : saturation light intensity (sensu Talling, 1957) Mean values $\pm 1 / 2 \times$ range $(n=3)$. Incubations were carried out nn 3 successive days

\begin{tabular}{|c|c|c|c|c|}
\hline Item measured & Ulva curvata & Dictyota dichotoma & Gracilaria foliifera & Codium decorticatum \\
\hline Thallus form & Flat sheet & Flat sheet & Subterete axis & Cylindrical axis \\
\hline Surface area: volume & 165 & Approx. 165 & 30 & 9 \\
\hline Thallus anatomy & Bilayer & $\begin{array}{l}3 \text { cells thick; cortex }+ \\
\text { medulla }\end{array}$ & Cortex + medulla & $\begin{array}{l}\text { Coenocytic; cortex }+ \\
\text { medulla }\end{array}$ \\
\hline Chloroplasts & $\begin{array}{l}\text { One per cell; } \\
\text { thylakoids stacked }\end{array}$ & $\begin{array}{l}\text { Many per cell; } \\
\text { thylakoids stacked }\end{array}$ & $\begin{array}{l}\text { Several per cell; } \\
\text { thylakoids single }\end{array}$ & $\begin{array}{l}\text { Numerous; thylakoids } \\
\text { stacked }\end{array}$ \\
\hline Antenna composition & $\operatorname{chl} a+b$ & chl $a+c_{1}$ fucoxanthin & chl $a$, phycobilins & chl $a+b$ \\
\hline Absorptance $\mathrm{b}^{\mathrm{b}}$ & 0.43 & 0.72 & 0.84 & 0.98 \\
\hline$P_{\max }{ }^{c}$ & $406 \pm 34$ & $435 \pm 84$ & $150 \pm 13$ & $116 \pm 23$ \\
\hline $\mathrm{I}_{k}{ }^{\mathrm{d}}$ & $465 \pm 200$ & $275 \pm 85$ & $200 \pm 75$ & $378 \pm 173$ \\
\hline Initial slope $e^{e}$ & $250 \pm 54$ & $536 \pm 214$ & $254 \pm 104$ & $111 \pm 54$ \\
\hline Dark respiration ${ }^{i}$ & $31 \pm 6$ & $82 \pm 29$ & $11 \pm 2$ & $14 \pm 2$ \\
\hline Photoinhibition ${ }^{b}$ & Weak & Weak & Strong & Moderate \\
\hline $\begin{array}{l}{ }^{a} \mathrm{~cm}^{2}: \mathrm{cm}^{3} \\
{ }^{b} \text { Ramus and Rosenberg (1980) }\end{array}$ & \multicolumn{2}{|c|}{$\begin{array}{l}{ }_{\mathrm{d}}^{\mathrm{c}} \mu \mathrm{mol} \mathrm{O}_{2} \text { evolved g dry } \mathrm{wt}^{-1} \mathrm{~h}^{-1} \\
\mu \mathrm{E} \mathrm{m}^{-2} \mathrm{~s}^{-1}\end{array}$} & \multicolumn{2}{|c|}{$\begin{array}{l}{ }^{e} \mu \mathrm{mol} \mathrm{O}_{2} \text { evolved g dry wt }{ }^{-1}\left(\mathrm{E} \mathrm{m}^{-2}\right)^{-1} \\
{ }^{\mathrm{t}} \mu \mathrm{mol} \mathrm{O} \mathrm{O}_{2} \mathrm{~g} \text { dry } \mathrm{wt}^{-1} \mathrm{~h}^{-1}\end{array}$} \\
\hline
\end{tabular}

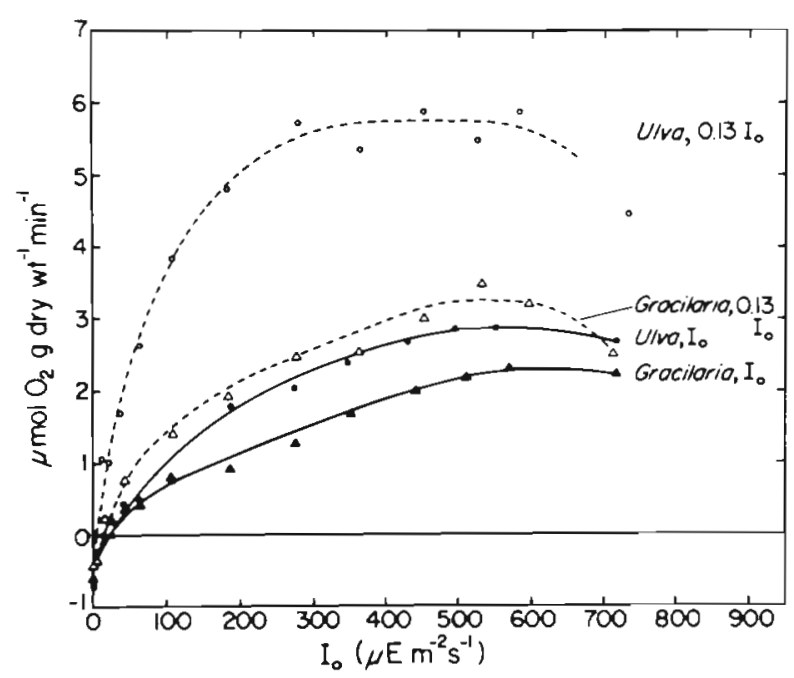

Fig. 1 Gracilaria foliifera and Ulva sp. Laboratory photosynthesis-light curves for November (1979) seaweeds acclimated for $2 \mathrm{wk}$ in outdoor continuous-flow seawater tanks at $I_{0}$ and .131. Each point represents the combined photosynthetic performance of 3 individuals. Curves were fitted by eye

lected Gracilaria foliffera and Ulva sp. (Table 1) with laboratory curves for acclimated plants (Fig. 1) suggests that the field-collected plants were closer in their photosynthetic characteristics (and antenna composition) to shade plants than to sun plants. In the case of $G$. foliifera, this has been substantiated by photosynthetic pigment analyses of field-collected specimens. The extent to which the natural populations are sun- or shade-acclimated may also depend on the time of year (see below).

Table 2 shows the photosynthetic performance of sun and shade plants of the 2 species measured outdoors in a Plexiglas tank at $.70 \mathrm{I}_{0}$ and $.03 \mathrm{I}_{0}$. The experimental light intensities $\left(.70 \mathrm{I}_{\circ}\right.$ and $.03 \mathrm{I}_{\circ}$, measured underwater) approximated the light intensities to which the seaweeds had been acclimated $\left(\mathrm{I}_{0}\right.$ and $.13 \mathrm{I}_{0}$, measured in air). Net photosynthesis of Ulva sp. exceeded that of Gracilaria foliifera at both $.70 \mathrm{I}_{0}$ and $.03 \mathrm{I}_{0}$. This applied to both sun and shade plants and was reflected in the higher growth rates (at $\mathrm{I}_{0}$ and $.13 \mathrm{I}_{0}$ ) observed in Ulva sp. over the preceding two weeks (Table 2). Sun plants of both species showed a higher rate of photosynthesis at $.70 \mathrm{I}_{\circ}$ than at .03I. On the other hand, shade plants showed a higher rate of photosynthesis at $.03 \mathrm{I}_{o}$ than at $.70 I_{0}$. This effect was particularly noticeable in shade plants of $G$. foliifera and was presumably due to increased sensitivity to photoinhibition in shade-acclimated plants (Fig. 1). The effect of shade acclimation was to enhance the photosynthetic performance of both species at .03I and of Ulva sp. at .70I。

For Gracilaria foliifera, the in vivo absorptance of shade plants was 2.6 times that of sun plants while Ulva sp. shade plants had an absorptance which was twice as high as in sun plants (Table 2). The difference spectrum for $G$. foliifera clearly showed that most of this increase was due to higher concentrations of $\mathrm{R}$ phycoerythrin.

\section{Antenna Pigments}

The seasonal fluctuations in the photosynthetic antenna pigments are shown in Fig. 2 (Gracilaria folifera) and Fig. 3 (Ulva sp.). Seaweeds grown at .13I had higher antenna pigment concentrations than seaweeds grown at $\mathrm{I}_{\mathrm{o}}$. Accessory pigment: chl a ratios (Fig. 4, 
Table 2. Gracilaria foliifera and Ulva sp. Photosynthetic performance of sun and shade plants measured outdoors in mid-October (1979) at .70I and .03I $\mathrm{I}_{0} \alpha$ in vivo absorptance; $\mu$ specific growth rate (from Rosenberg, 1981 ); $R$ dark respiration; $P_{n}$ net photosynthesis. $\mu$ : Mean values $\pm \sigma(n=32) ; R, P_{n}$. Mean values $\pm 1 / 2 \times$ range $(n=2)$

\begin{tabular}{|c|c|c|c|c|c|c|}
\hline Species & $a^{\mathrm{a}}$ & $\mu^{b}$ & $\mathrm{R}^{\mathrm{c}}$ & $\mathrm{P}_{\mathrm{n}}{ }^{\mathrm{d}}$ at $0.70 \mathrm{I}_{0}$ & $P_{n}$ at $0.03 I_{0}$ & $\frac{P_{n} \text { at } 0.03 I_{0}}{P_{n} \text { at } 0.70 I_{o}}$ \\
\hline \multicolumn{7}{|c|}{ Gracilaria foliifera } \\
\hline Sun & 0.30 & $9.3 \pm 3.9$ & $37 \pm 7$ & 93 & $50 \pm 6$ & 0.54 \\
\hline Shade & 0.78 & $7.6 \pm 4.5$ & $33 \pm 3$ & $71 \pm 17$ & $164 \pm 20$ & 2.32 \\
\hline \multicolumn{7}{|l|}{ Ulva curvata } \\
\hline Sun & 0.10 & $36.9 \pm 7.4$ & $40 \pm 3$ & $126 \pm 22$ & $89 \pm 21$ & 0.70 \\
\hline Shade & 0.20 & $15.9 \pm 7.0$ & $32 \pm 2$ & $206 \pm 10$ & $311 \pm 13$ & 1.51 \\
\hline \multicolumn{7}{|c|}{ 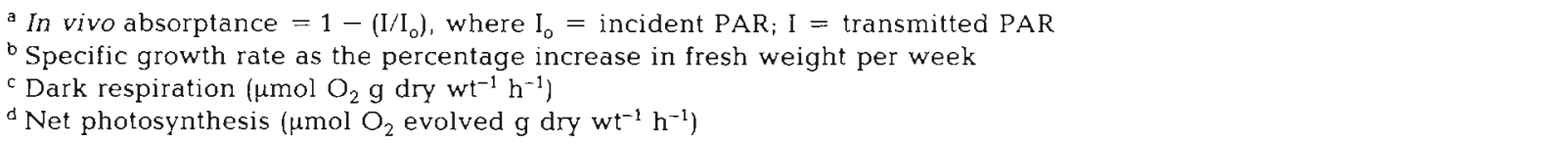 } \\
\hline
\end{tabular}

Table 3) were usually higher at $13 \mathrm{I}_{\mathrm{o}}$ than at $\mathrm{I}_{\mathrm{o}}$ (paired t-test, $\mathrm{p}<.01$ for $G$. foliifera, $\mathrm{p}<.05$ for Ulva sp.). In $G$. foliifera, most of the variation in total pigment content was due to fluctuation in the levels of R-PE. Thus, at $I_{0}$,

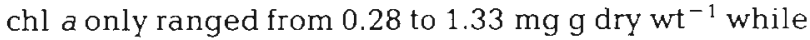

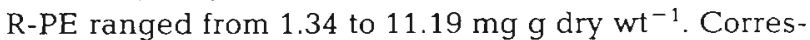
ponding figures at $.13 \mathrm{I}_{0}$ were 0.43 to $1.25 \mathrm{mg} \mathrm{g}$ dry $\mathrm{wt}^{-1}$ for chl $a$ and 4.56 to $15.22 \mathrm{mg} \mathrm{g} \mathrm{dry} \mathrm{wt}^{-1}$ for R-PE. These figures for $G$. foliifera are in agreement with those of LaPointe and Ryther (1979). In Ulva sp., the chlorophyll a concentration was more variable. At $\mathrm{I}_{0}$,

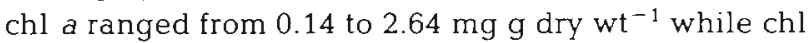

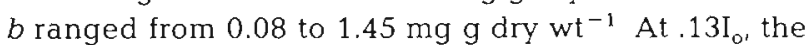
ranges for chl $a$ and $b$ were 0.29 to $3.50 \mathrm{mg} \mathrm{g} \mathrm{dry} w t^{-1}$

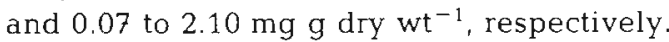

At both $\mathrm{I}_{0}$ and $.13 \mathrm{I}_{0}$, antenna pigment concentrations were correlated with the levels of soluble tissue $N$ (Figs. 2 and $3 ; \mathrm{r}=.90, \mathrm{p}<.001$ for R-PE in Gracilaria foliifera; $\mathrm{r}=.56, \mathrm{p}<.01$ for chl $a$ in Ulva sp.). In particular, during the April-to-September growing season, $\mathrm{N}$-nutrient pulses in the ambient seawater resulted in peaks in both soluble tissue $\mathrm{N}$ and antenna pigments in July ( $G$. foliifera) and September (both species). Low growth rates in the fall and winter coincided with the accumulation of soluble $\mathrm{N}$ within the thallus and correspondingly high antenna pigment concentrations. In $G$. foliifera, R-PE alone accounted for about one third of the total protein (Rosenberg, 1981).

Overall, antenna pigment concentrations were highest in fall and winter and lowest in spring and summer. In Gracilaria foliifera, since variations in total antenna pigment content were mostly due to fluctuations in $\mathrm{R}$ PE, the R-PE: chl a ratio was also highest in fall-winter and lowest in spring-summer (Fig. 4). The trends for the minor biliproteins (not shown) followed those described for R-PE. In Ulva sp., the chl b:a ratio did not show any pronounced seasonal trends (Table 3 ).
Nevertheless, there was some evidence that the pigment ratios responded to changes in light intensity to different extents and, occasionally, in different directions (e.g. in April-May; Table 3) at different times of year. This may partly depend on the state of the pigments and the nutrient status in the freshly collected plants prior to acclimation.

The total carotenoid concentrations were higher in Ulva sp. than in Gracilaria foliifera at both $\mathrm{I}_{\circ}$ and $.13 \mathrm{I}_{0}$ (Figs. 2 and 3). In $G$. foliifera, the total carotenoid concentrations at $I_{0}$ and $.13 I_{0}$ were not significantly different (paired t-test, $\mathrm{p}=.06$ ). On the other hand, Ulva sp. grown at $.13 \mathrm{I}_{\circ}$ had higher total carotenoid concentrations than plants grown at $I_{0}$ (paired t-test, $\mathrm{p}<.001)$. The ratio of total carotenoids to total chlorophyll was similar in both species and did not vary seasonally (Table 4 ). This ratio was usually higher at $I_{0}$ than at $.13 I_{0}$ (paired t-test, $p<.001$ for $G$. foliifera). However, in Ulva sp., this difference was not significant (paired t-test, $\mathrm{p}=.12$, df $=13$ ) unless the April-May data are not included $(p<.001$, df $=11)$.

\section{DISCUSSION}

The higher growth rates achieved by Ulva sp. in comparison with Gracilaria folifera reflected the photosynthesis-light curves for the 2 species. At a time (October, 1979) when the ratio of the in situ $\mathrm{P}_{\max }$ values for freshly collected plants was 2.7:1 (Ulva sp:: G. foliffera; Table 1), the ratio of the specific growth rates for 2-wk acclimated plants was 4.0:1 at $\mathrm{I}_{\mathrm{o}}$ and 2.1:1 at $.13 \mathrm{I}_{\mathrm{o}}$ (Table 2). The higher $\mathrm{P}_{\max }$ value for Ulva sp. was characteristic despite the variability (including seasonal and nutrient-related effects) to which such P vs. I curves are known to be subject (Ramus and Rosenberg, 1980)

Together with the data for Dictyota dichotoma and 

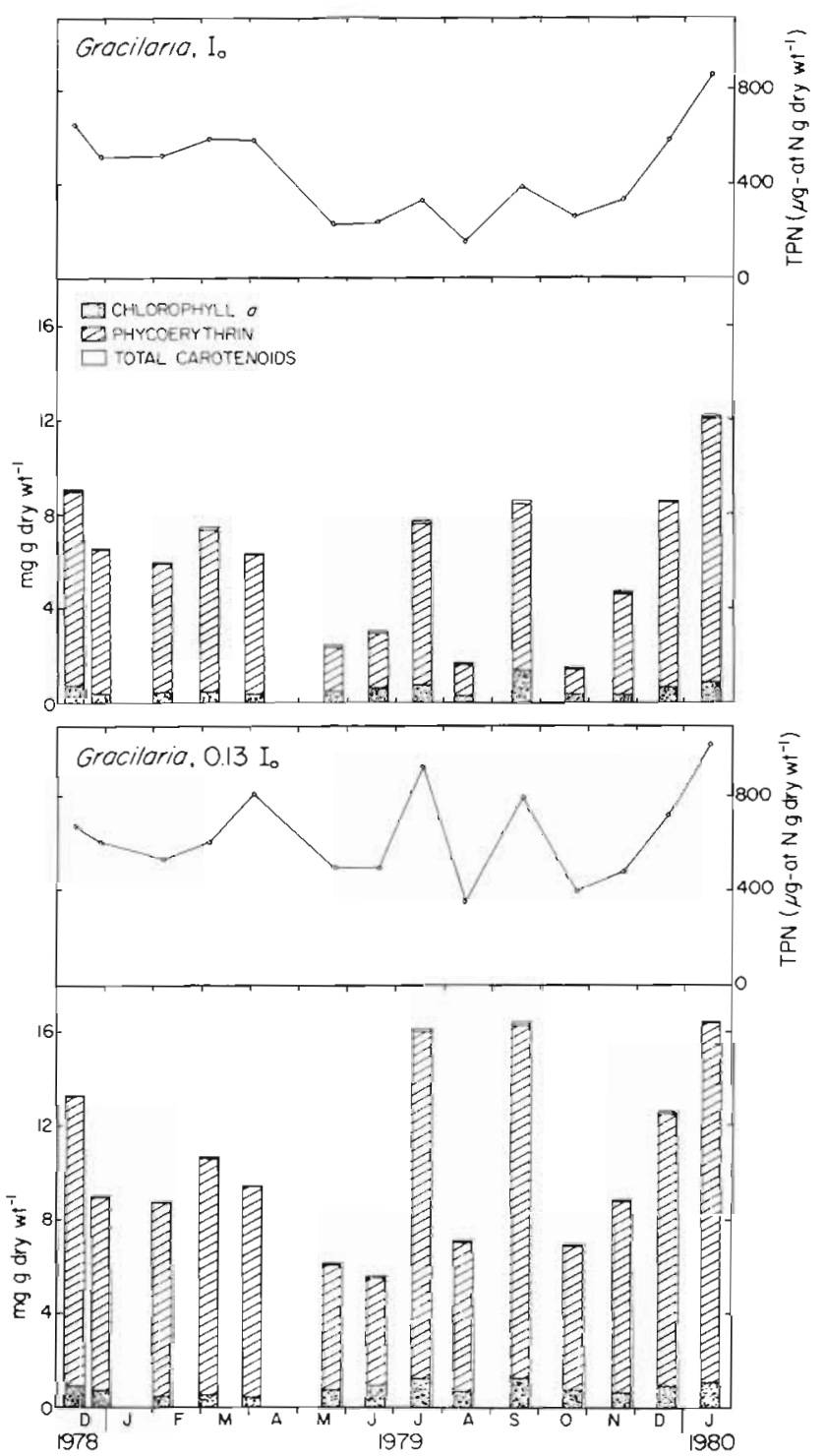

Fig. 2. Gracilaria foliifera. Composite graph showing seasonal changes in soluble tissue $N$ ( $\mu$ g-at $N$ gdrywt ${ }^{-1}$ ) and major photosynthetic antenna pigments (mg gdrywt ${ }^{-1}$ ) in seaweeds grown in outdoor continuous-flow cultures at $I_{o}$ and $.13 \mathrm{I}_{\mathrm{o}}$. TPN total persulfate nitrogen

Codium decorticatum, these results showed higher productivity in the thin, sheet-like species with high surface area: volume ratios than in the thicker species with low SA:V ratios. In general, this ratio seems to be a better predictor of $P_{\max }$ (but not necessarily initial slope; cf. Ramus, 1978) than the identity of the antenna pigments, the in vivo absorptance, or the internal thallus and chloroplast anatomy (Table 1 i Littler and Murray, 1974; Littler, 1980). Nutrient uptake rates have also been found to be correlated with the SA:V ratio (Rosenberg, 1981).

Although the photosynthetic performance and

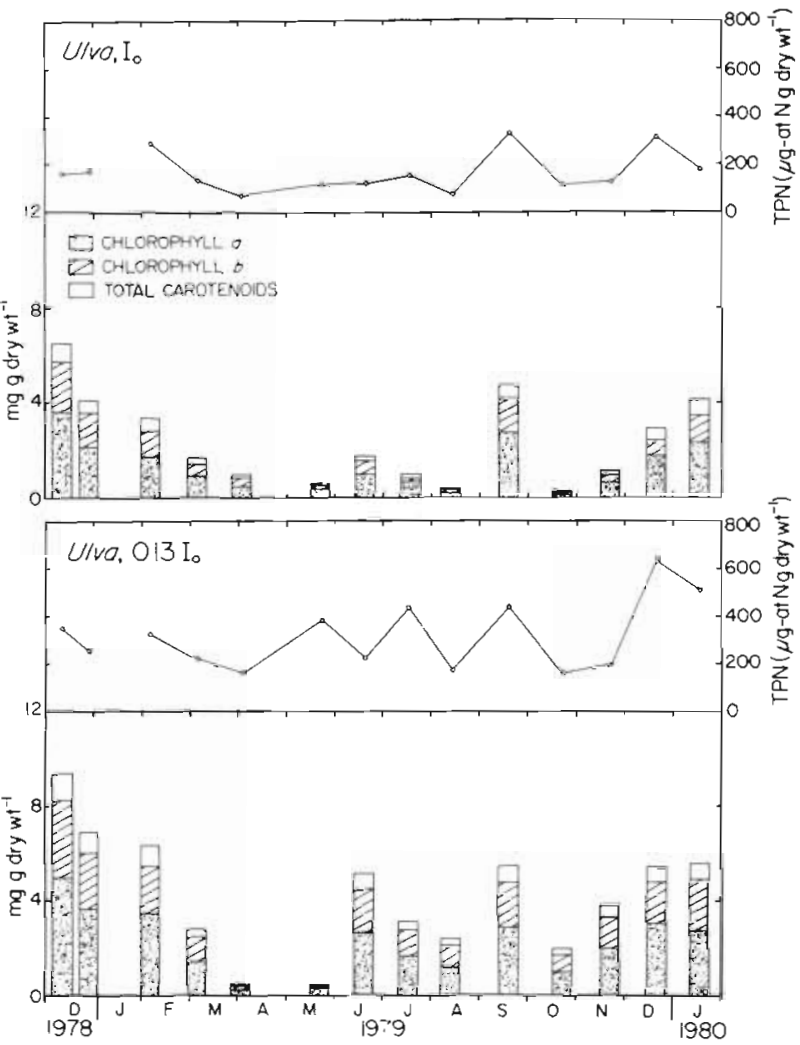

Fig. 3. Ulva sp. Composite graph showing seasonal changes in soluble tissue $\mathrm{N}$ and antenna pigments in seaweeds grown in outdoor continuous-flow cultures at $\mathrm{I}_{0}$ and $.13 \mathrm{I}_{0}$. TPN total persulfate nitrogen

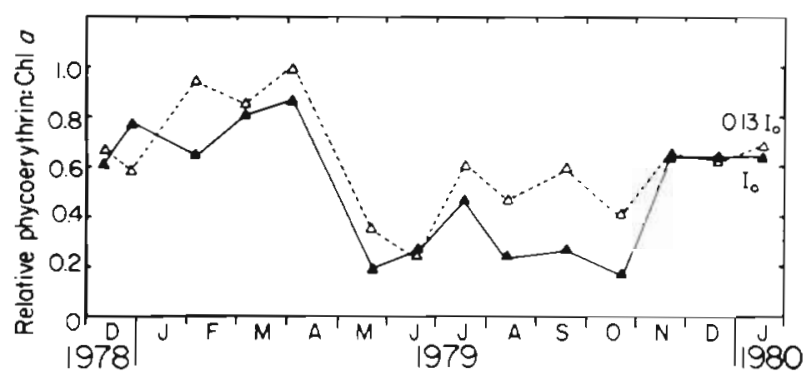

Fig. 4. Gracilaria foliifera. Seasonal changes in the relative ratio (by weight) of R-phycoerythrin to chl a in plants grown at $\mathrm{I}_{\mathrm{o}}$ and $13 \mathrm{I}_{\mathrm{o}}$. R-phycoerythrin and chl a determined in separate samples

growth rates of Ulva sp. exceeded those of Gracilaria foliifera at both $\mathrm{I}_{\mathrm{o}}$ and $.13 \mathrm{I}_{0}$, there are indications that this relationship may be reversed at very low light intensities. Using deep shade acclimated plants sampled from natural populations, Ramus and Rosenberg (1980) found that the integrated diurnal net photosynthesis of $G$. foliifera at .03I not only exceeded that of Ulva sp., but was higher than its own diurnal net photosynthesis at $.70 \mathrm{I}_{0}$. This would not be predictable from the P-I curves of Fig. 1 and emphasizes the desira- 
Table 3. Ulva sp. Chlorophyll b: chlorophyll a ratios (molar basis) for seaweeds grown in outdoor continuous-flow cultures at $I_{0}$ and $.13 \mathrm{I}_{0}$. Dates refer to last day of 2 -wk acclimation periods. Mean values $\pm \sigma(\mathrm{n}=5)$

\begin{tabular}{|c|c|c|c|}
\hline & \multirow{2}{*}{ Date } & \multicolumn{2}{|c|}{ Chlorophyll $b: a$ (moles) } \\
\hline & & $\mathrm{I}_{\mathrm{o}}$ & $0.13 \mathrm{I}_{0}$ \\
\hline Dec & 11,1978 & $.60 \pm .01$ & $.64 \pm .01$ \\
\hline Dec & 28 & $.67 \pm .03$ & $.64 \pm .02$ \\
\hline $\mathrm{Feb}$ & 5,1979 & $.60 \pm .03$ & $.56 \pm .04$ \\
\hline Mar & 5 & $.57 \pm .09$ & $73 \pm 11$ \\
\hline Apr & 2 & $.72 \pm .05$ & $.53 \pm .07$ \\
\hline May & 22 & $.33 \pm .13$ & $.22 \pm .04$ \\
\hline Jun & 19 & $.62 \pm .05$ & $.67 \pm .03$ \\
\hline Jul & 17 & $.29 \pm .14$ & $.67 \pm .07$ \\
\hline Aug & 13 & $.67 \pm .05$ & $.65 \pm .05$ \\
\hline Sep & 18 & $.54 \pm .01$ & $.65 \pm .03$ \\
\hline Oct & 22 & $.57 \pm .08$ & $.71 \pm .02$ \\
\hline Nov : & 21 & $.48 \pm .05$ & $.69 \pm .05$ \\
\hline Dec & 20 & $.38 \pm .02$ & $.56 \pm .02$ \\
\hline Jan & 17,1980 & $.51 \pm .03$ & $.73 \pm .10$ \\
\hline \multicolumn{2}{|l|}{ Mean } & $.54 \pm .13$ & $.62 \pm .13$ \\
\hline
\end{tabular}

Table 4. Gracilaria folifera and Ulva sp. Ratio of total carotenoids: total chlorophyll (molar basis, assuming an average carotenoid molecular weight $=600$ ) for seaweeds grown in outdoor continuous-flow cultures at $I_{0}$ and $.13 I_{0}$. Dates refer to last day of 2 -wk acclimation periods. Mean values $\pm \sigma$ $(\mathrm{n}=5)$

\begin{tabular}{|lccccc|}
\hline \multicolumn{2}{c}{ Date } & \multicolumn{2}{c}{ Gracilaria } & \multicolumn{2}{c|}{ Ulva } \\
& & $\mathrm{I}_{\mathrm{o}}$ & $0.13 \mathrm{I}_{\mathrm{o}}$ & $\mathrm{I}_{\circ}$ & $0.13 \mathrm{I}_{\mathrm{o}}$ \\
\hline Dec 11,1978 & $14 \pm .01$ & $13 \pm .02$ & $.21 \pm .01$ & $.21 \pm .01$ \\
Dec 28 & $18 \pm .04$ & $.11 \pm .03$ & $.22 \pm .01$ & $.21 \pm .01$ \\
Feb 5,1979 & $.12 \pm .01$ & $.14 \pm .05$ & $.28 \pm .02$ & $.22 \pm .01$ \\
Mar 5 & $.22 \pm .10$ & $.20 \pm .05$ & $.28 \pm .04$ & $.21 \pm .01$ \\
Apr 2 & $19 \pm .03$ & $.23 \pm .09$ & $.23 \pm .01$ & $.38 \pm .02$ \\
May 22 & $.27 \pm .03$ & $19 \pm .03$ & $.28 \pm .02$ & $.40 \pm .05$ \\
Jun 19 & $.24 \pm .07$ & $.17 \pm .03$ & $.22 \pm .01$ & $.21 \pm .01$ \\
Jul 17 & $.22 \pm .04$ & $15 \pm .01$ & $.31 \pm .02$ & $.21 \pm .01$ \\
Aug 13 & $.25 \pm .03$ & $16 \pm .01$ & $.23 \pm .01$ & $.21 \pm .01$ \\
Sep 18 & $.21 \pm .03$ & $.19 \pm .02$ & $.22 \pm .01$ & $.20 \pm .01$ \\
Oct 22 & $.21 \pm .01$ & $.14 \pm .02$ & $.27 \pm .03$ & $.22 \pm .01$ \\
Nov 21 & $.26 \pm .06$ & $.13 \pm .01$ & $.30 \pm .03$ & $.22 \pm .01$ \\
Dec 20 & $.25 \pm .03$ & $.15 \pm .02$ & $.32 \pm .01$ & $.21 \pm .01$ \\
Jan 17.1980 & $.19 \pm .01$ & $14 \pm .01$ & $.29 \pm .02$ & $.20 \pm .01$ \\
Mean & $.21 \pm .04$ & $.16 \pm .03$ & $.26 \pm .04$ & $.24 \pm .07$ \\
\hline
\end{tabular}

bility of carrying out measurements of diurnal photosynthetic performance for comparative purposes (Ramus and Rosenberg, 1980). Furthermore, the in vivo absorptance of shade-acclimated $G$. foliifera increased by a greater percentage than that of shade-acclimated Ulva sp. (Table 2). It is noteworthy that, in the Beaufort area, $G$. foliifera is typically found in pure stands in deeply shaded areas and under overhanging rocks. Further work needs to be done in order to determine whether or not there is a light intensity threshold below which $G$. foliifera would have a higher growth rate than Ulva sp. This may depend on the thresholds for photostress responses, including loss of photosynthetic units (PSU) (Prézelin and Sweeney, 1978) and ribulose-1,5-bisphosphate carboxylase (RuBPCase) activity (Beardall and Morris, 1976), in these 2 species.

Shade acclimation is only one factor promoting increased antenna pigment levels in seaweeds. At a particular light intensity, peaks in pigment content of Gracilaria foliifera and Ulvasp. tended to follow peaks in ambient $\mathrm{N}$-nutrient availability. Increased pigment content in response to nitrogen enrichment has also been observed in the red seaweeds Neoagardhiella baileyi (DeBoer and Ryther, 1978) and Gracilaria foliifera from Florida (LaPointe and Ryther, 1979).

Photosynthetic pigment content and, in Gracilaria foliifera, the R-PE: chl a ratio, were also higher during winter, at a time of low growth rates, than in summer. Similar seasonal patterns for total pigment content have been reported for the red seaweeds Chondrus crispus (Rhee and Briggs, 1977), Eucheuma isiforme (Moon and Dawes, 1976), and Hypnea musciformis (Durako and Dawes, 1980), as well as for several brown fucoids (Jensen, 1966; Zavodnik, 1973; Brinkhuis, 1977). In Hypnea musciformis and Fucus virsoides (Zavodnik, 1973), pigment content was correlated with protein levels in the thallus. This is not surprising inasmuch as it is likely that a considerable fraction of this protein was directly associated with the photosynthetic antenna (Ramus, in press). Although part of the seasonal variability was undoubtedly due to nutrient availability, none of these studies reported fluctuations in inorganic nitrogen levels in the ambient seawater. The increase in the ratio of total carotenoids to total chlorophyll at high photon flux density and its apparent seasonal constancy in G. foliffera and Ulva sp. is consistent with the proposed role of carotenoids in protecting against photo-oxidation and stabilizing the chlorophyll-protein complex (Krinsky, 1968).

In general, the main effect of increased antenna pigment content is to increase the photosynthetic performance expressed on a biomass basis (Fig. 1) and, thus, the carbon capital available for growth. This has been observed in seaweeds sampled from natural populations (Zavodnik, 1973; Mishkind et al., 1979), in seaweeds which were shade-acclimated in situ (Ramus et al., 1976b, 1977), in seaweeds which have been $N$ enriched (Chapman et al., 1978; LaPointe and Ryther, 1979), and within individual plants (Wheeler, 1980). Shade acclimation per se may (Fig. 1; Table 2) or may not (Ramus et al., $1976 \mathrm{~b}, 1977$ ) result in a greater sensitivity to photoinhibition. It is worthwhile to note that this condition did not occur in Laminaria sac- 
charina in which high pigment levels were brought about by nitrogen enrichment (Chapman et al., 1978). This suggests that photosynthetic acclimation to low photon flux density and high nitrogen levels may involve different mechanisms at the biochemical level.

This may have important consequences for seaweeds growing in a nitrogen-limited environment such as the Beaufort region (Thayer, 1974). Peaks in N-nutrient availability occurred as pulses rather than as a seasonal maximum. By taking advantage of these pulses to increase their antenna pigment contents temporarily, Gracilaria foliifera and Ulva sp. would be able to step up their photosynthetic capacity until such a time as tissue nitrogen levels must be drawn down in order to sustain continued growth.

In the winter, although tissue $\mathrm{N}$ was high (Figs. 2 and 3), growth rates were low. Other factors (such as light or temperature) must have been limiting seaweed growth at this time. The effect of increased pigment content in winter would thus be to limit the decrease in integrated net photosynthesis in the face of decreased light and temperature. The high tissue $\mathrm{N}$ levels and pigment contents at $13 \mathrm{I}_{\mathrm{o}}$ (Figs. 2 and 3) certainly reflect shade acclimation and light-limited growth. Nevertheless, high pigment levels at $.13 \mathrm{I}_{\mathrm{o}}$ and in the winter did not result in the maintenance of the high growth rates observed at $\mathrm{I}_{0}$.

Further work needs to be done in order to test this hypothesis. In particular, it is necessary to determine how growth under different $\mathrm{N}$-nutrient loading regimes affects the P-I curve and how this compares to curves representing acclimation to shade and low temperature. It is likely that the responses to nitrogen enrichment involve metabolic processes beyond the realm of the photosynthetic antenna, including RuBPCase activity and electron transport. Only when this information becomes available will it become possible to understand seasonal variations in pigment content in the context of seaweed growth strategies.

Acknowledgements. This research was supported by National Science Foundation grants OCE $77-27130$ (to G. R.) and OCE 18698 (to J. R.) from the Biological Oceanography Program. We are grateful to the Yale Biology Department for graduate student support. We also thank the Duke University Marine Laboratory for providing research facilities and Dr. M. J. Dring for comments which improved the manuscript.

\section{LITERATURE CITED}

Beardall, J., Morris, I. (1976). The concept of light intensity adaptation in marine phytoplankton: some experiments with Phaeodactylum tricornutum. Mar Biol. 37: 377-387

Brinkhuis, B. H. (1977). Seasonal variations in salt-marsh macroalgae photosynthesis. II. Fucus vesiculosus and Ulva lactuca. Mar Biol. 44: 177-186
Chapman, A. R. O., Markham, J. W., Lüning, K. (1978). Effects of nitrate concentration on the growth and physiology of Laminaria saccharina (Phaeophyta) in culture. J. Phycol. 14: $195-198$

DeBoer, J. A., Ryther, J. H. (1978). Potential yields from a waste-recycling algal mariculture system. In: Krauss, R. (ed.) The marine plant biomass of the Pacific northwest coast. Oregon State University Press, Corvallis, pp. 231-249

D'Elia, C. F., Steudler, P. A., Corwin, N. (1977). Determination of total nitrogen in aqueous samples using persulfate digestion. Limnol. Oceanogr. 22: 760-764

Durako, M. J., Dawes, C. J. (1980). A comparative seasonal study of two populations of Hypnea musciformis from the east and west coasts of Florida, USA. I. Growth and chemistry. Mar. Biol. 59: 151-156

Jeffrey, S. W., Hymphrey, G. F. (1975). New spectrophotometric equations for determining chlorophylls $a_{1} b, c_{1}$ and $c_{2}$ in higher plants, algae, and natural phytoplankton. Biochem. Physiol. Pfl. 167: 191-194

Jensen, A. (1966). Carotenoids of Norwegian brown seaweeds and of seaweed meals. Rep. Norw. Inst. Seaweed Res. 31: $1-138$

Krinsky, N. I. (1968). The protective function of carotenoid pigments. In: Giese, A. C. (ed.) Photophysiology, Vol. 3. Academic Press, London and New York, pp. 123-195

LaPointe, B. E., Ryther, J. H. (1979). The effects of nitrogen and seawater flow rate on the growth and biochemical composition of Gracilaria folifera var. angustissima in mass outdoor cultures. Botanica mar. 22: 529-537

Littler, M. M. (1980). Morphological form and photosynthetic performance of marine macroalgae: tests of a functional form hypothesis. Botanica mar. 22: 161-165

Littler, M. M., Murray, S. N. (1974). The primary productivity of marine macrophytes from a rocky intertidal community. Mar. Biol. 27: 131-135

Mishkind, M., Mauzerall, D., Beale, S. I. (1979). Diurnal variation in situ of photosynthetic capacity in Ulva is caused by a dark reaction. Pl. Physiol. 64: 896-899

Moon, R. E., Dawes, C. J. (1976). Pigment changes and photosynthetic rates under selected wavelengths in the growing tips of Eucheuma isiforme (C. Agardh) J. Agardh var denudatum Cheney during vegetative growth. Br. phycol. J. 11: 165-174

Platt, T., Denman, K. L., Jassby, A. D. (1977). Modeling the productivity of phytoplankton. In: Goldberg, E. D. (ed.) The sea, Vol.6. John Wiley \& Sons, New York, pp. $807-856$

Prézelin, B. B., Sweeney, B. M. (1978). Photoadaptation of photosynthesis in Gonyaulax polyedra. Mar. Biol. 48: $27-35$

Provasoli, L., Pintner, I. J. (1980). Bacteria-induced polymorphism in an axenic laboratory strain of Ulva lactuca (Chlorophyceae). J. Phycol. 16: 196-201

Ramus, J. (1978). Seaweed anatomy and photosynthetic performance: the ecological significance of light guides, heterogeneous absorption, and multiple scatter. J. Phycol. 14: 352-362

Ramus, J. (in press). The capture and transduction of light energy. In: Lobban, C., Wynne, M. (eds.) The biology of seaweeds. Blackwell, Oxford

Ramus, J., Beale, S. I., Mauzerall, D., Howard, K. L. (1976a). Changes in photosynthetic pigment concentration in seaweeds as a function of water depth. Mar. Biol. 37: 223-229

Ramus, J., Beale, S. I., Mauzerall, D. (1976b). Correlation of changes in pigment content with photosynthetic capacity 
of seaweeds as a function of water depth. Mar. Biol. 37 : $231-238$

Ramus, J., Lemons, F., Zimmerman, C. (1977). Adaptation of light-harvesting pigments to downwelling light and the consequent photosynthetic performance of the eulittoral rockweeds Ascophyllum nodosum and Fucus vesiculosus. Mar Biol. 42: 293-303

Ramus, J., Rosenberg, G. (1980). Diurnal photosynthetic performance of seaweeds measured under natural conditions. Mar. Biol. 56: 21-28

Rhee, C., Briggs, W. R. (1977). Some responses of Chondrus crispus to light. I. Pigmentation changes in the natural habitat. Bot. Gaz. 138: 123-128

Rosenberg, G. (1981). Ecological growth strategies in the seaweeds Gracilaria foliifera (Rhodophyceae) and Ulva sp. (Chlorophyceae). Ph. D. thesis, Yale University, New Haven, Connecticut

Siegelman, H. W. Kycia, J. H. (1978). Algal biliproteins. In: Hellebust, J. A., Craigie, J. S. (eds.) Handbook of phy- cological methods: physiological and biochemical methods. Cambridge University Press, London, pp. 71-79

Strickland, J. D. H., Parsons, T R. (1972). A practical handbook of seawater analysis, 2nd ed., Fisheries Research Board of Canada, Ottawa

Talling, J. F. (1957). Photosynthetic characteristics of some freshwater plankton diatoms in relation to underwater radiation. New Phytol. 56: 29-50

Thayer, G. W. (1974). Identity and regulation of nutrients limiting phytoplankton production in the shallow estuaries near Beaufort, N. C. Oecologia (Berl.) 14: 75-92

Wheeler, W. N. (1980). Pigment content and photosynthetic rate of the fronds of Macrocystis pyrifera. Mar Biol. 56: $97-102$

Zavodnik, N. (1973). Seasonal variations in rate of photosynthetic activity and chemical composition of the littoral seaweeds common to the north Adriatic. Part I. Fucus virsoides (Don) J. Ag. Botanica mar. 16: 155-165

This paper was presented by Dr. M. J. Dring; it was accepted for printing on February 19, 1982 